\title{
Are Immigrants Paid Less for Education?*
}

\author{
Lubomira Anastassova \\ CERGE-EI $^{\dagger}$
}

WP 406

\begin{abstract}
This paper is on measuring the gap in returns to education between foreign-born and native workers in France, Germany, and Austria and investigates the extent to which this gap can be explained by a mis-match between the actual and the years of schooling typical for a given occupation. The return to usual years of schooling across different occupations is found to be higher than that for actual years of education. In the case of correctly matched workers who have the 'typical' education in a certain occupation, there is no additional reward in earnings for natives compared to foreign workers. Immigrants, however, have significantly lower wage returns in being over-educated than natives but are penalized less for being under-educated.
\end{abstract}

\begin{abstract}
Abstrakt
Tento článek měří rozdíl v návratnosti vzdělání mezi imigranty (narozenými v cizině) a domácími pracujícími ve Francii, Německu a Rakousku. Ptá se také, do jaké míry lze tento rozdíl vysvětlit rozdíly ve vzdělání imigrantů oproti typické úrovni vzdělání v kategoriích zaměstnaní, ve kterých imigranti pracují. Návratnost vzdělání uvnitř zaměstnání je nejvyšší pro typickou úroveň vzdělání a pro takto "správně" vzdělané pracující v něm není rozdíl mezi domácími a zahraničními pracujícími. Na druhou stranu imigranti mají oproti domácím pracujícím významně nižší návratnost vzdělání pokud jsou "př́liš" vzdělaní pro své zaměstnání a naopak jsou méně penalizováni za "nedostatečné" vzdělání vůči úrovni obvyklé v dané kategorii zaměstnání.
\end{abstract}

Keywords: immigrants, schooling, occupations, earnings, rates of return. JEL classification: F22, I21, J24, J31, J61.

\footnotetext{
* I would like to thank Štěpán Jurajda, Ira Gang, Randall Filer, Alexandru Chirmiciu and Michael Jetton for their valuable suggestions and comments. This research has been supported by a grant from the CERGE-EI Foundation under a program of the Global Development Network. All opinions expressed are those of the author and have not been endorsed by CERGE-EI or the GDN.

${ }^{\dagger}$ CERGE-EI is a joint workplace of the Center for Economic Research and Graduate Education, Charles University, Prague, and the Economics Institute of the Academy of Sciences of the Czech Republic. Address: CERGE-EI, Politických vězñů 7, Prague 1, 110 00, Czech Republic.

E-mail: Lubomira.Anastassova@cerge-ei.cz.

This paper was supported by Center of Advanced Political Economy Research [Centrum pro pokročilá politicko-ekonomická studia], No. LC542, (2005-2009)
}

(C) 2010 The Author 


\section{Introduction}

The relationship between education and its impact on earnings has been explored extensively by many economists. Accounting for the earning differential between migrant and native workers based on their schooling, however, is still relevant and an interesting research topic for both practitioners and policy makers given the flexible and highly competitive labour markets of the developed economies. Different educational systems across countries pose a real challenge for policy makers in recognizing the educational degrees and technical skills of foreign-born workers in their countries. This may lead to foreign-born workers being employed in occupations where the average level of education across employed workers is higher or lower than their own education level, which could translate into a potential mis-match in earnings between natives and migrants.

Duncan and Hoffman (1981) started the literature by distinguishing between an individual's actual years of schooling and the 'typical' years of schooling prevailing in a certain job. Studies based on US data (e.g., Chiswick, 1980; Duncan and Hoffman, 1981; Cohn and Khan, 1995) suggest that the rate of return (impact on earnings) to 'typical' schooling is positive across occupations and exceeds that of over-education, while the return to under-education is negative.

This type of an analysis has been also applied to understanding why immigrants typically face lower returns to education compared to natives. Chiswick \& Miller (2005) imply that the partial effect of an additional year of schooling on earnings for foreignborn workers in the USA is 2.5 percentage points lower than that for natives. Potential explanations for this phenomenon are that either human capital skills are not fully transferable across borders or that a year of schooling has a different human capital content across countries. Alternatively, migrants may face barriers in the labour market that result in fewer opportunities to find a job and thus may receive wages below their marginal productivity. One such example is work permits linked to specific job positions or geographical areas as in the case of the temporary restricted free movement 
of labour with respect to the countries that joined the European Union in 2004 and $2007 .{ }^{1}$

A number of studies confirm the above premises and document an increase in the dispersion of labour market outcomes across immigrants examining data for Canada, Germany, Portugal and UK. ${ }^{2}$ However, recent evidence from large EU economies is not available, which makes further research on the topic necessary and important in view of recent and future EU expansions and in view of recent large migration flows towards the developed Western labour markets. Furthermore, gathering evidence on the extent to which potential educational mis-matches occur between years of schooling and the 'typical' years of schooling prevailing in a certain occupation and its impact on earnings across natives and migrants in different countries could shed further light on the effectiveness of immigration policies across countries. A comparison between the educational returns to earnings of migrants versus natives subject to the conservative immigration policy of France, Germany, and Austria (analysed in this paper) on the one hand and the less restrictive immigration and integration policy of the UK and US (data based on existing studies) on the other will provide valuable insight into the success of these immigration policies and how well integrated migrants are across countries. ${ }^{3}$

In this paper, I therefore extend the existing evidence of educational returns to earnings for natives and immigrants, by focusing on three European economies, Germany, France and Austria, which are characterized by substantial immigration flows during the last 40 years. By 1993, the total number of non-EU residents in the Community had reached 12 million. Of these migrants, one-quarter were Turks, who mainly resided in Germany and another quarter from North Africa were residing in France. In 2003, the number of legally resident foreigners in Germany was 7.3 million, who comprised 8.9 percent of the total population, while France had 4.9 million immigrants representing roughly 8.1 percent of its population. The analysis (regression estimates) on France, Germany, and Austria, characterised by a rather conservative labour market access to immigrants, is compared further to those by previous studies on

\footnotetext{
${ }^{1}$ See Refugees, Recent Migrants and Employment, Challenging Barriers and Exploring Pathways (2008), edited by Sonya McKay, Routledge Economics

${ }^{2}$ See Baker and Benjamin (1994); Chiswick (1980); Kiker \& Santos (1991); and Dustmann (1993). Groot and Maasen van den Brink (2000) provide a survey of the literature.

${ }^{3}$ See "Immigration policy and the welfare system" (2002) edited by T. Boeri, H. H. Hanson, and B.

McCormick ; and see also Entorf \& Minoiu (2005).
} 
migrants' earnings in the USA (Chiswick \& Miller, 2007) and in the UK (Lindley \& Linton, 2006), exhibiting a more flexible labour market access. ${ }^{4}$

The data are drawn from the Luxembourg Income Study (LIS), which transforms the original data files into a harmonized LIS data format, synchronizes definitions and labour market concepts, and makes all dataset variables comparable across different countries. This allows for an easy and robust comparison of the impact of years of education on the earnings of native and immigrant workers across the economies of Germany, France, and Austria ${ }^{5}$, which differ both in the size and composition of their migrant populations as well as in their migration policies over time. The decomposition of the actual years of schooling variable into 'typical' education (the actual years of schooling match the years of schooling prevailing usually across occupations); over-education (the actual years of schooling higher than those typical across occupations); and under-education (the actual years of schooling lower than those typical across occupations) will provide an insight into the overall gap in payoffs to schooling.

I find no significant difference in the impact of 'typical' education on earnings between native and migrant workers in all countries of analysis, which shows that there is no additional reward in earnings in the case of natives compared to foreign workers. However, foreign-born workers find it slightly more difficult to find employment in occupations matching their level of education. Furthermore, the return to usual years of schooling that prevail amongst workers across different occupations is higher and statistically different than that for actual years of education for both native and foreignborn workers in all countries. However, compared to natives, foreign-born workers have lower returns to over-education, which drive the gap in earnings between natives and the foreign-born. This could potentially be the evidence for differences in the 'quality' of education between native and foreign-born employees. Foreign-born workers find it more difficult to find jobs matching their education and may also face lower earnings than natives for similar levels of education beyond the prevailing level in a given occupation.

\footnotetext{
${ }^{4}$ See Boeri et al. (2002) and M. Caldeira, J. Castello, A. Esteves, A. Ferrer, M. Fonseca, J. Jamin, H. Koff, A. Lostia, J. Malheiros, I. Molina, E. Tricada and J. van der Leun (1999).

${ }^{5}$ The choice of countries is based on availability of data
} 
Differences in immigration policies with respect to labour market access do not play a role while comparing the educational returns of native and migrant workers who have found a position perfectly corresponding to their education. The gap between educational returns of natives and workers across all countries in this case is nonexistent. However, France, Germany, and Austria reward their native workers more than they reward immigrants in the case where these workers have more years of schooling than that typical of workers in their occupation. In contrast, the UK and the US do not differentiate between migrant and native workers in rewarding over-education. 


\section{Theoretical Background}

\section{Over-education/Under-education Theories}

Hartog (2000) and Kiker, Santos, and Mendes De Oliveira, (1997) outline four different interpretations of the over/under-education phenomena: (i) a search and match framework in an environment of imperfect information, (ii) the human capital framework, (iii) the hedonic/assignment framework and (iv) the technological change framework.

Search and Match theory focuses on the existence of an 'educational mis-match' due to imperfect labour market information. This mis-match is only a temporary phase since it is directly related to the individual's age and experience on the labour market. Workers with a given level of education search to improve their job level and move in cases where the offer is better than their current position overtime. Thus, the incidence of over-education falls with increasing age and experience and the incidence of undereducation at the same time decreases. The searching and matching interpretation is very likely to explain the initial educational mis-match of migrants whose qualifications were not recognized by the host country and who progress into better jobs over time.

Human Capital theory suggests that over-education results from the individual's choice of accepting a lower-level job in his early years of experience since it is a good investment opportunity. Sicherman (1991) shows that workers who have higher education than that 'typical' for the job are more likely to move to higher level occupations. This theory is supported by Alba-Ramirez (1993) who finds that overeducated workers are more likely to move to better occupations, while under-educated workers move to a similar job position within their occupation. The lack of international transferability of skills and the fact that a year of schooling for migrants could be different than a year of schooling for natives are among the reasons of why migrants could appear to be over-educated or under-educated, while in fact they are correctly matched with respect their actual schooling.

The Assignment Theory represented by the Sattinger (1993) paper for example, focuses on measuring the match between assigned heterogeneous workers to heterogeneous jobs. Within the general hedonic model, a job is characterized by a fixed 
level of 'typical' education, and individuals with varying levels of education might be assigned to this job. Equilibrium could be achieved by the free interaction of the demand for labour expressed as job requirements and the supply for labour expressed as workers applying for a particular job. For a given job level, the reward to attained education reflects the value of this particular education to the employer in the shape of an iso-profit curve. This curve is expected to be concave, or, in other words, the negative impact on earnings (penalty) of under-education should be larger than the positive impact on earnings (reward) of over-education. In general, returns to education depend on the specificities of the job, and the earnings difference between workers with different education varies due to the success of the assignment or the match.

The Technological Change Framework is to be found in Kiker et al. (2000) and suggests that the skills an individual acquires at school should be constantly improved so that they match and keep up with the technological changes in a country. Thus, these graduates will be more educated than their co-workers once they find a job. The employers are not able to hire immediately all those better educated workers, and hence, the existing workers will become in reality under-educated. Once the job requirements evolve, however, so that they reflect the skills and education of the newly hired graduates, these graduates will be considered over-educated with respect to those who are already on the job. According to this theory, for a given level of education immigrants from less-developed countries have an education that is based on a more distant technology than the developed economies and therefore are more likely to report that they are over-educated compared to immigrants from developed economies in an attempt to secure a job position.

In summary, according to both the Search and Match theory and the Human Capital theory, the incidence of under- and over-education diminishes over time with higher age and accumulated experience by individuals. While the first theory predicts that both over- and under-education occur less with the increasing of an individual's age and experience, the latter suggests that over-educated workers are likely to progress to better occupations compared to under-educated workers, who often move across similar positions within the same occupation. The Assignment theory predicts a higher earnings penalty of under-education compared to the over-education reward on earnings, while the Technological Change theory claims that immigrants from less-developed 
economies are more frequently over-educated compared to immigrants from developed economies.

\section{Over-education/Under-education measurement and the existing literature}

The positive relationship between education and earnings is well acknowledged by the economics literature. While the human capital models of Becker (1964) and Mincer (1974) assume that the education of a worker is fully utilized by his current occupation, the job competition model developed by Thurow (1975) suggests a more complicated relationship between education and earnings, which still advocates, however, a rigid structural view of jobs. Proponents of the latter view claim since the job market allocation is based on existing surpluses/shortages between individuals and jobs, some workers are likely to possess higher or lower education and skills than those typical in their job. Under this assumption, each occupation is characterized by a 'typical' level of education that is needed for a satisfactory job performance (see Kiker et al., 1997; Hartog, 2000). Any worker's education above this 'typical' level is known as "over-education" and any education below the 'typical' level of education is "undereducation".

An important issue in the literature on over-education and under-education is how the 'typical' schooling is measured. There are three possible approaches regarding that issue depending on the perspective of defining the 'typical' education for a certain job: the job analysis approach, the worker self-assessment approach, and the realizedmatches approach. ${ }^{6}$ According to the job analysis approach, the 'typical' level of education is specified for the different job titles across occupations by professional job analysts. Rumberger (1987) provides the empirical evidence for the above approach by using the US Dictionary of Occupational Titles and finds that over-educated workers in the US have lower rates of return than workers with the 'typical' level of education.

The worker self-assessment approach uses the information provided by the worker himself on what level of education is 'typical' in a certain occupation, or what is the typical minimum level of education required to perform the current job satisfactorily. This approach is used by Duncan and Hoffman (1981), who confirm the 
results of Rumberger (1981) based on US data. Daly, Buchel and Duncan (2000) also employ the worker self-assessment approach in comparing the returns to over-education and under-education between the US and Germany and find that for both countries, surplus education receives a wage premium, while deficit education suffers a wage penalty.

The third method of realized matches, which I use in this paper, postulates that 'typical' education is indicated by the actual schooling of the workers in a particular occupation measured by the mean or the mode of that distribution. Any schooling that is above the mode/mean years of schooling for a certain occupation is considered to be over-education, and any schooling below the 'typical' education is respectively undereducation. A comparison of the benefits and drawbacks of all three approaches is given by Hartog (2000). ${ }^{7}$ He performs analyses using all three approaches and concludes that the results are not sensitive to the approach employed to measure 'typical' education.

Verdugo and Verdugo (1989) use the mean and the standard deviation of schooling based on the 1980 US census as a benchmark for the 'typical' level of education. They find that over-educated workers earn less than their either adequately educated or under-educated counterparts and claim that the returns to over-schooling are negative. Cohn and Kahn (1995) replicate the analysis by Verdugo and Verdugo (1989) and Sicherman (1991) using the 1985 wave of the Panel Study of Income Dynamics. While Verdugo and Verdugo (1989) claim that the returns to over-education are negative, Cohn and Kahn (1995) conclude that the returns to over-education are positive and those to under-education are negative.

Daly et al. (1998) analyze American and German data over the 1970s and 1980s in an attempt to compare structural differences between countries regarding labour markets and the educational mis-match. They find that workers who have more schooling than typical for their job are rewarded, and those who have insufficient schooling are penalized with regards to earnings. Despite the fact that Germany has a much more structured educational system and labour market than the United States, the data show more similarities across countries than over time.

\footnotetext{
${ }^{6}$ For a detailed explanation of the three approaches see Hartog (2000).

${ }^{7}$ Though the realized matches approach has its drawbacks, the job analysis approach could give biased evaluations if the actual years of schooling of workers across occupations are used, rather than the typical education for a particular type of job.
} 
Kiker et al. (1997) use the mode of the years of education as a reference for the required or 'typical' level of education of workers in Portugal. Chiswick and Miller (2008) use the U.S. 2000 Census and the mode of years of education to analyze the extent of matching educational attainment among native and foreign-born workers of working age. They find that migrants who have entered the labour market recently tend to be overeducated, while immigrants who have stayed longer in the country are more likely to be under-educated.

Lindley \& Lenton (2009) use UK Quarterly Labour Force Survey 1993-2003 to explore the incidence of over- and under-education and among natives and immigrants with UK degrees, and the impact of the educational mis-match on earnings. The authors find that compared to Whites, Black African, Other Non-White, and Indian men are more likely to be over-educated, whilst for women it is Indians and Pakistani/Bangladeshi's who are more likely to be over-educated.

The mode of years of schooling, which I use in this paper, is a different measure of the 'typical' education which does not suffer from some of the drawbacks in using the mean value (for example the frequency of the actual years of education required to perform a certain job might substantially differ from the occupational mean). However, as a robustness check of defining the 'typical' education I use also the mean and the standard deviation of the actual years of schooling and compare the results to those when the mode of schooling has been used.

While exploring the differences in returns to education among workers has initially driven research forward, concentrating on possible educational differences and their impact on earnings between natives and immigrants makes an additional contribution to the existing literature, given the recent and future EU expansion and the recent large migration flows towards the developed Western labour markets. 


\section{Data Description and Empirical Strategy}

In this paper, I consider three European countries - France, Germany and Austria and compare a standard Mincerian specification using actual years of education to a Realized-Matches Approach specification, where the 'typical' education is defined by the mode of the education of workers in each occupation. The analysis is based on Luxembourg Income Study (LIS) ${ }^{8}$ data and covers France (2000); Germany (2000); and Austria (2000). The LIS is a micro-database compiled from labour force surveys from different countries. It provides demographic background information, work status and employment characteristics, at both the household and individual level. At the individual level, the LIS includes such demographic variables as age, marital status, the highest degree of education attained, ethnicity, migration status, and labour force status. The advantage of the LIS data is that they are comparable across countries because the original data files are transformed into a harmonized LIS data format.

The aim of this paper is to compare the value of immigrant education systems (years of schooling) to the host country with respect to earnings across different economies. Since the seminal work of Becker (1964), economists view the choice of education in the context of a utility maximizing individual, who invests in education as long as the present value of the costs of investment equals the present value of the returns to this investment. The Mincerian wage equation (Mincer, 1974), which has been applied extensively in a multitude of studies, allows for a straightforward crosscountry comparison in calculating the return to education.

I analyze employed individuals of working age. The main specification employed in the analysis is as follows:

$Y=\mathrm{f}$ (Education, Experience, Control Variables)

The monthly average earnings of the workers are expressed as a function of workers' education, experience, and different control variables, which characterize the workers and have a potential impact on their wages. In an attempt to take account of a potential mis-match on education in the labour market for each country, I estimate both Mincerian and Realized-Matches Approach specifications: 
1 (Mincerian) In Yi $=\beta_{0}+\beta_{1}$ Education $_{i}+\beta_{2} \operatorname{Exp}_{i}+\beta_{3} \operatorname{Exp}_{i}^{2}+\beta_{4}$ Married $_{i}+\ldots+u_{i}$, and

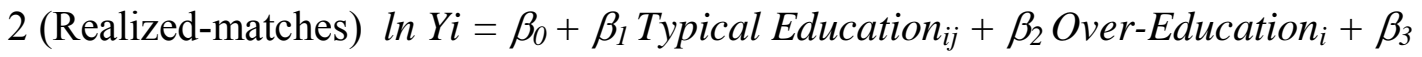

Under-Education Ed $_{i}+\beta_{4} \operatorname{Exp}_{i}+\beta_{5} \operatorname{Exp}_{i}^{2}+\beta_{6}$ Married $_{i}+\ldots+u_{i}$

where $\ln Y i$ is the natural logarithm of the monthly earnings per worker; Education ${ }^{9}$ is the actual worker's years of schooling ${ }^{10}$; 'Typical' Education is the mode value of workers' years of schooling prevailing in the occupation ${ }^{11}$; Over-Education ${ }^{12}$ equals the years of schooling above the 'typical' education and Under-Education are the years of schooling below the 'typical' education; $\mathrm{i}=$ worker and $\mathrm{j}=$ occupation.

The main difference between the two specifications is the education variable. In the standard Mincerian equation, earnings and education are correlated in a log-linear fashion. ${ }^{13}$ The Realized-Matches Approach allows, however, for a more flexible approach, whereby returns (earnings) to education vary depending on whether the individual has a 'typical' education, over-education, or under-education. Therefore, each worker would be either over-educated, under-educated, or have adequate education (correctly-matched) similar to the usual years of education prevailing among the workers in his current occupation, which means that for every employee, either overeducation or under-education or both must be zero.

Alongside the education variables, both specifications allow for a range of control variables to explain the outcome: potential labour experience (approximated by the standard formula of ([Age - Years of Schooling - 6]); a dummy variable for marital

\footnotetext{
${ }^{8}$ www.lisproject.org

${ }^{9}$ There is no perfect measure of education, and formal years of schooling are often used to approximate a given 'skill set' acquired by the individual. Therefore, the education variable is subject to a measurement error and is to be treated with caution.

${ }^{10}$ The years of schooling have been imputed from the highest completed level of general education. For further details see Robustness Checks in section IV Mincerian vs. the Realized-Matches Approach.

${ }^{11}$ The occupational variable across all countries is at a two-digit level based on the 4-digit ISCO-88 standard classification. Originally, Germany had 4-digit occupational information, which had to be aggregated to a two-digit level so that it would be comparable to the occupational information available in France and Austria.

${ }^{12}$ Both over- and under- education are not exogenous variables; they approximate unobserved ability such as language skills. These variables are subject to a higher measurement error than the 'typical' education variable due to the fact that individuals in these categories exhibit a-typical levels of education.

${ }^{13}$ Tables A.1, A.2, and A.3 present the different educational levels in Austria, France, and Germany and their corresponding years of schooling.
} 
status; a geographical dummy for different regions; a company ownership dummy indicating whether the worker is employed in a state or private enterprise; and a sectoral dummy indicating whether the sector of employment is industry, services, or agriculture. ${ }^{14}$ Two additional control variables in each specification indicate whether the worker has a permanent fixed-term contract of employment, and whether he has a supervisory role which involves managing other co-workers or not.

Table 1 presents the incidence of educational mis-match among employed workers aged 16-60/64, according to the criteria of the Realized-Matches Approach, i.e. how many of them are correctly educated (have the 'typical' education), over-educated or under-educated. When the actual years of education of a worker are higher than the mode of years of schooling among workers in a certain occupation, he is considered to be over-educated, and when his years of education are lower than the same mode, he is under-educated. Equality between the education of an employee and the modal years of schooling across different occupations qualify him to be correctly educated (matched), which means that he has the usual years of education typical for his occupation.

The average years of schooling ${ }^{15}$ across native and foreign-born ${ }^{16}$ workers in each country are presented in the first column of Table 1. In Austria the average years of schooling are 12 independently from the worker's country of birth. The foreign-born workers in both France and Germany have on average 9 years of schooling, while the French native workers have studied on average for 11 years as opposed to 10 years in the case of German native workers. This could also be illustrated by distributional charts (Chart 1, Chart 2, and Chart 3) of actual years of schooling for each of the three countries of analysis. More than 60 percent of all workers in Austria have 12 years of schooling, which is equivalent to having a high school diploma. In France and Germany, the dispersion is higher given that in France 25 percent of the workers have 11 years of schooling (graduated secondary school), and 45 percent of workers have 9 years of schooling (general high school education) in Germany.

\footnotetext{
${ }^{14}$ One disadvantage of the data is that there is no information on years since migration for the foreignborn workers though in Chiswick and Miller (2005), this variable has a minor impact on earnings.

${ }^{15}$ The average years of schooling have been calculated as the average of the modes across all occupations in a country.

${ }^{16}$ Foreign-born workers are defined as all workers born outside the country of analysis. The terms foreign-born workers and immigrant workers are used interchangeably throughout the paper.
} 
Taking into account the modal value of the actual years of schooling for each worker's occupation, Austria has the highest proportions of correctly matched native and foreign-born workers across all countries of analysis: 73 percent correctly matched native workers and 62 percent correctly matched immigrants. In Germany, there are an almost equal proportion of correctly matched natives (50 percent) and correctly matched immigrants (46 percent), whereas in France, 37 percent of native workers are correctly matched as opposed to 27 percent for the foreign-born workers.

The incidence of over-education is quite significant and equally distributed among native and immigrant workers in Germany (35 percent), while in France, workers are less frequently over-educated (26 percent of native and 21 percent of foreign-born workers). The lowest levels of over-education among workers are in Austria, where only 5 percent of native workers are over-educated compared to 11 percent of foreign-born workers.

The incidence of under-education is highest in France, where almost 52 percent of foreign-born workers are under-educated as opposed to 38 percent across native workers.

A further indication of a potential mis-match is provided by the ratio of overeducated workers in low-skilled occupations or under-educated workers in highly skilled occupations ${ }^{17}$. In Germany, the proportions of over-educated native and foreignborn workers in low-skilled occupations are similar at 36 percent, while in France there are more over-educated native workers in low-skilled occupations (25 percent) compared to foreign-born workers (20 percent). Under-educated foreign-born workers in high-skilled occupations are in higher proportion than their native counterparts across all three countries of analysis. The highest proportion of foreign-born under-educated workers in highly skilled occupations is in France where 44 percent of foreign-born workers have the above characteristic.

More than 50 percent of all native and foreign-born workers are married where the presence of a spouse is higher across foreign-born workers in all three countries. Similarly, more than half of all workers in France, Germany, and Austria are employed

\footnotetext{
${ }^{17}$ Highly skilled occupations are defined here as those occupations where the majority of workers have a post-secondary education (more than a high-school diploma), or highly educated workers have a $10 \%$ wage premium with respect to less educated workers. For details see Gottschalk and Hansen (2003).
} 
on a permanent contract basis, and a substantial percentage of native and foreign-born workers in France (60 percent) and Austria (50 percent) have a supervisory position.

Table 2a presents a comparison of the differences between native and immigrant workers' educational mis-matches across countries. The data from Austria, France, and Germany are contrasted to the UK (1993-2003) and the USA (2000) data presented by Lindley and Linton (2006) and Chiswick and Miller (2005) respectively. ${ }^{18}$ In all countries, the percentage of correctly matched native workers is higher than that for immigrant workers, but the gaps in the UK and the USA are larger than in their continental European counterparts. In France, Germany, and the USA, over-educated immigrant workers are less frequently over-educated than their native co-workers that share similar characteristics. The UK and Austria are the two countries where overeducated foreign-born employees are more frequent than over-educated native workers. In all countries of analysis, immigrants are more frequently under-educated than natives with the exception of the UK. The gap between under-educated foreign-born and native workers is highest in the USA (18 percentage points), followed by France, where the corresponding gap is 14 percentage points.

If the distribution of correctly matched-, over- and under-educated is normalised by the native-foreign-born distributions, a clearer picture emerges in Table $2 b$. In this table, any ratio above 1 indicates that the proportion of natives in realised-matches (or over-/under-education) is higher than the proportion of natives in the entire sample, i.e. natives are over-represented. Conversely, a ratio below one indicates that natives are under-represented (or foreign-born workers are over-represented). In all three countries, native workers are substantially over-represented in jobs with a correct match of education. In France and Germany, there are proportionally more native over-educated workers, and in all three countries, foreign-born workers are proportionately more under-educated. Similarly to incidences for the US and the UK, these statistics suggest that there is a structural difference between native and foreign-born workers.

\footnotetext{
${ }^{18}$ The UK data focuses only on white male natives versus white male immigrants, while the data for the U.S. is restricted only to males.
} 


\section{Mincerian vs. the Realized-Matches Approach}

Tables 3, 4, and 5 present the regression estimates of the standard Mincerian Approach as opposed to the Realized-Matches Approach for natives and the foreignborn in France, Germany, and Austria for the year 2000. The first two columns in each table refer to native workers, while the last two columns pertain to foreign-born workers.

\section{Natives}

The Mincerian specification for natives across the three countries of analysis confirms the positive and significant relationship between actual years of schooling and earnings. Each additional year of schooling accounts for a 6.2 percent increase in the earnings of a native French worker; 6.5 percent for every German worker; and 7.8 percent in the case of a native Austrian employee.

The partial effect of labour experience on earnings varies with years of experience and is given by accounting for both coefficients for experience and experience ${ }^{2} / 100$ and taking the first derivative with respect to experience. Thus, the fifth year of potential employment experience after finishing formal education for a French native worker, for example, yields a 2.7 percent increase in his earnings; 4 percent increase in the earnings of a German employee; and a 1.5 percent increase for a native Austrian worker.

Amongst many control variables (region, gender, industry) present in the Mincerian specification for native workers, three variables are of interest and have a significant impact on earnings. Employment on a permanent contract basis benefits the earnings of native workers across all three countries in the range of 30-35 percent on average. Work-positions which have a supervisory role and involve managing people are also a significant driver of wage earnings and contribute by an average of 20 percent to higher wages across France and Austria, and a 35 percent increase in earnings in the case of Germany. ${ }^{19}$ The ownership of the worker's company, i.e. whether the company is private or state-owned is a significant variable and somewhat surprisingly suggests

\footnotetext{
${ }^{19}$ Note that this is equivalent to the average wage premium for supervisory positions, but the data do not allow for a more granular distinction between the various supervisory or management positions.
} 
that working for a private company will have a $10-15$ percent negative impact on the earnings of workers across France, Germany, and Austria.

Once we use the Realized-Matches Approach and account for the prevalent years of education across the workers of a certain occupation, the impact of the 'typical' education on earnings among native workers in all countries of analysis is higher than that for the actual years of education. These results are in full accordance with other studies on the American and Canadian economies (Chiswick and Miller, 2009 and Vahey, 2000). The returns to 'typical' education range from 8 per cent to 8.8 per cent, some 2 percentage points higher than that for the actual years of education in the case of native workers in France and Germany and 1 percentage point in Austria. A year of over-education among native workers contributes to a 6.8 percent increase in earnings for the French worker, 3.6 percent for the German worker, and 7.7 percent for the Austrian worker, which is substantially less than the return to 'typical' education. In contrast, a year of education less than the usual years of education among workers in a certain occupation has a negative impact on native workers' earnings as follows: -4.2 percent in France, -6.7 percent in Germany, and -7 percent in Austria.

\section{Foreign-born}

Employing both Mincerian and the Realized-Matches Approach analysis for foreign-born workers (the last two columns of tables 3, 4, and 5) shows similar dynamics in the earnings function for foreign-born workers across the countries of analysis. The actual years of education have a 5 percent positive impact on earnings of foreign-born workers in France; 3 percent for immigrants in Germany; and 4 percent for those in Austria. In contrast, once the Realized-Matches Approach is used and the usual years of education prevailing among the workers across occupations are taken into account, the impact of the 'typical' education on earnings increases to 7 percent in France; 9 percent in Germany; and exceeds 10 percent in Austria ${ }^{20}$. Given that this tendency is observed among both native and foreign-born workers across all three countries suggests that earnings are explained better by the usual years of education typical in a given occupation, rather than by the actual years of schooling pertaining to

\footnotetext{
${ }^{20}$ The slope coefficients of actual years of education and those for 'typical education' are significantly different across all countries of analysis (France $\mathrm{p}=0.03$, Germany $\mathrm{p}=0.05$, and Austria $\mathrm{p}=0.06$ ).
} 
each individual worker. Thus for a given occupation the individual's level of education in relation to the prevailing 'typical' level of education in that occupation is the most relevant driver of earnings. The best returns are for the education years precisely up to the 'typical' level, with a smaller premium for each additional year of over-education. The occupation and the prevailing level of education amongst workers in this occupation are more important in defining one's earnings than his diploma and actual years of study. However, the actual years of study partly influence the choice of occupation and successful employment.

The positive impact of over-education on earnings varies between 1 percent for Germany and 4 percent for France, while under-education penalizes foreign-born workers by 3.6 percent of their earnings in France; 5 percent in Germany; and 4 percent in Austria. All other explanatory variables in the Realized-Matches Approach for foreign-born workers share a similar magnitude to their equivalents in the Mincerian specification.

\section{Foreign-born vs. Natives}

The standard Mincerian specification in tables 3, 4, and 5 allows for the comparison of actual years of education and their impact on earnings between native and foreign-born workers. The native-immigrant gap in returns to actual years of education is 3 percentage points in favour of native workers in Germany and Austria, and 1 percentage point in France.

Table 6 provides the Realized-Matches Approach education estimates on earnings and allows for a comparison between native and foreign-born workers across countries. The native-immigrant gap in 'typical education' in France and Germany is 1 percentage point, 2 percentage points in Austria, 1.5 percentage points in the UK (Lindley \& Linton, 2006), and does not exist in the USA (Chiswick and Miller, 2007). When accounting for the usual years of schooling across occupations, the gap of the 'typical' education estimates between the correctly matched native and foreign-born workers across all countries is not statistically significant. This finding suggests that if a migrant succeeds in finding a job requiring his actual years of schooling, then the impact of her education on earnings is similar to that of a native worker independent of how strict the immigration policy is in the country. 
The years of education above the usual years of education of workers across occupations have a greater positive impact on the earnings of natives than on the wages of foreign-born workers. The gap of over-education estimates between native and foreign-born workers is significant in France and Germany at around 2.5 percentage points in favour of native workers. An additional year of over-education among native workers in the UK and the USA has on average, a greater impact on earnings than that for foreign-born workers with a gap in over-education estimates of 1.5 percentage points for the UK and 1.1 percentage points in the United States. The same tendency is valid for Austria, where the native-immigrant over-education gap is 5 percentage points but, however, is not significant. Over-educated native workers in the EU countries (France, Germany, and Austria) with stricter immigration policies are rewarded significantly more than foreign-born workers in comparison to the more liberal US and the UK.

When the education of a worker is less than the usual level of years of education of his occupational colleagues, this under-education has a negative impact on earnings. Foreign-born workers, however, are penalized less ${ }^{21}$ than their native co-workers across all countries of analysis with the exception of the $\mathrm{UK}^{22}$. The native-immigrant undereducation gap is the highest in the USA and is 4.4 percentage points in favour of foreign-born workers, followed by Austria with 3.1 percentage points, 1.6 percentage points in Germany, and almost 1 percentage point in France and the UK. The less conservative immigration policy in the US, results in penalizing under-educated migrants less than their native counterparts.

Tables 3, 4, and 5 provide further information when comparing the rest of the control variables in the Realized-Matches Approach specification between native and foreign-born workers. The experience of foreign-born workers has a smaller impact on their earnings, in comparison to native workers, but has however a positive and significant impact on earnings across all three countries. Workers with permanent contracts or taking supervisory positions are likely to have similar higher earnings than those who have fixed-term contracts, and do not supervise other workers regardless of whether they are native or foreign-born workers across all the countries of analysis.

\footnotetext{
${ }^{21}$ Note that the migrant population may be subject to a selection bias.

${ }^{22}$ The native-immigrant gap in under-education is not significant for the UK.
} 
Combining the results from table 6 together with table $2 \mathrm{~b}$ provide some interesting insights into the native-migrant gaps in educational impact on earnings across countries. On the one hand, table 6 shows that the relatively liberal with regards to immigration policy ${ }^{23}$, UK and US economies value the over-education of migrants and natives equally (the over-education gap being approximately zero), while France, Germany, and Austria, countries that pursue a more conservative immigration policy, reward over-educated natives more than over-educated migrants. On the other hand, table $2 \mathrm{~b}$ shows that the efficiency of the labour markets in the UK and the US is lower than that in the other three countries with respect to typical education and overeducation in the case of the UK. In the case of Austria, the incidence of the overeducation of migrants is higher than that for natives with respect to the corresponding total numbers of natives and migrants due to the relatively small number of overeducated migrants and the overall low variability in years of education for both natives and migrants, which requires additional caution when interpreting the regression results. $^{24}$

The combination of the selection on quality (high-education, high skills) through immigration policy and of the matching efficiency of the labour markets (see Table $2 b$ ) could potentially explain the fact that the UK and the US attract some of the best educated and highly skilled immigrants despite the flaws in the matching mechanism in their labour markets.

\section{Robustness checks}

One drawback of the data is that the years of schooling have been imputed from the highest completed level of education for each individual, an approach known for having a downward bias on the returns to schooling. ${ }^{25}$ The imputation was rather straightforward given that the highest completed degree by each individual corresponds to certain years of education typical for the educational system in each country. Despite the differences in educational systems across Austria, France, and Germany, in all

\footnotetext{
${ }^{23}$ Liberal immigration policy refers to easier access to the labour market for immigrants as opposed to a conservative immigration policy referring to a more difficult access to the labour market in the host country.

${ }^{24}$ Please note that the immigrants' sample for Austria is substantially smaller than for the other countries of analysis.

${ }^{25}$ See Munich, Svejnar and Terrell (2005)
} 
countries the high-school diploma corresponds to 12 years of education on average, while a university degree corresponds to 18 years of education. A further concern with regards to imputing the years or schooling from the highest completed level of education is the degrees in different countries could have a different meaning, which makes the comparison between them a challenging task. For example, the fact that most of the foreign-born workers in France come from North Africa (Morocco, Algeria, and Tunisia) is not that alarming given that all these countries were French colonies in the past, and their educational systems are based on the French educational system, which facilitates the comparison between the educational degrees of their workers. While the years of schooling required for getting a degree might not be that different between countries, the quality of education and the educational institutions across countries do differ and make employers more sceptical of the skills and experience based on degrees held by foreign-born workers compared to natives. To tackle this issue, I conducted robustness checks of the returns to education of immigrants coming from a certain geographic area (e.g. Eastern Europe, Northern Africa). The coefficients are very similar and not significantly different from the ones received when all immigrants were considered as one group, which might suggest that the extent of imputation bias between these two regions is similar or the differences in the human-capital context in these areas work in opposite directions.

A potential concern is that the immigrant variable does not make a distinction between EU and non-EU immigrants. Workers from EU-member countries can move freely within the European Union as a matter of right, while non-EU members will be at least partially selected by the receiving country (visa, working permits, etc.) In the case of Austria and Germany, once the EU/non-EU split is made, the size of the immigrant sample is too small for any meaningful analysis to be made. However, in France there are 504 migrants born in other EU counties, and 1100 non-EU migrants. The regression analysis shows that there is no significant difference in the educational coefficients between the EU migrants and the non-EU migrants ${ }^{26}$ both for the Mincerian and the Realised-Matches Approach.

The information on occupations varies across countries. In Germany the occupational variable is based on a 4-digit ISCO-88 standard classification. This

\footnotetext{
${ }^{26}$ Results are available upon request.
} 
variable had to be aggregated to a two-digit level, so that it is fully comparable with the other two countries of analysis: France and Austria. As a sensitivity-check of the German occupational data, different regressions were run, where the occupational variable was at three digit-level and the resulting coefficients were not significantly different from those acquired when using occupations at a two-digit level.

In this paper all estimations are based on defining the 'typical' education as the mode of the actual years of schooling prevailing across occupations. Considering the caveats related to the measurement of education, robustness checks were employed to test the sensitivity of the results to the definition of the 'typical' education. Defining the 'typical' education as either one year less or more than the data derived, the mode of education in each occupation yields very similar results. Thus under these sensitivity scenarios ${ }^{27}$ the coefficient estimates are slightly different compared with the standard estimation in all three country datasets, which translates into negligible differences in terms of the effects of education on earnings. Furthermore, I use also the mean and a range of one standard deviation of the actual years of schooling when defining the 'typical' education, and compare the results to those when the mode of schooling has been used. There are no significant differences in the impact of education on earnings when the mean of actual years of schooling is used as a benchmark for 'typical' education. $^{28}$

\section{High-skilled vs. Low-skilled occupations}

In recent decades, the labour markets in the developed economies have been characterised by a constantly growing demand for 'college'-educated or highly skilled workers due to the increasing importance of the strong skill-biased technological change experienced by these economies. Therefore, the distinction between high-skilled occupations (those that demand predominantly highly skilled or college workers) on the one hand and low-skilled occupations (those that demand predominantly low-skilled or non-college workers) on the other and how they differ with regards to educational returns is important in analysing the native-migrant educational impact on earnings.

\footnotetext{
${ }^{27}$ Given the potential correlation between the education variable and other regressors such as permanent contract or supervisory position dummies, both Mincerian and Realised-Matches regressions were run omitting those variables. The coefficients for education are not significantly different from those when these regressors are included. Results are available upon request.
} 
There are multiple definitions of 'college' and 'non-college' occupations, which in essence focus on explaining the concept of over-education (see McGuiness 2006 for a review) but the Gottschalk and Hansen (2003) approach provides the most useful insight into the educational impact on earnings of natives as opposed to immigrants since it is based solely on economic outcomes. Gottschalk and Hansen (2003) define automatically college and non-college occupations when one type of worker (highlyeducated or a college worker with more than a high-school diploma or a less-educated or non-college worker with a high-school diploma) is strongly prevailing. The authors define college (high-skilled) occupations as those occupations where more than $90 \%$ of the workers have higher or college education, and non-college (low-skilled) occupations as those occupations where more than $90 \%$ of the workers have a lower or non-college education. For those occupations where there is no clear majority of workers with college or non-college education, a 10\% college wage premium threshold applies, i.e. an occupation is classified as a college (high-skilled) occupation when it pays at least a $10 \%$ premium to highly educated (college) workers. In this paper, I use the same thresholds as those used by Gottschalk and Hansen (2003). Table 7 shows the regression estimates of returns to education based on the Mincerian and Realized-Matches specifications for France and Germany.

Focusing on the Realized-Matches specification and comparing Table 6 to Table 7 , the estimates for the correctly matched, over-educated and under-educated natives working in high-skilled occupations in Table 7 are similar to their equivalents in Table 6 in both France and Germany. However, comparing the regression estimates for French migrants shows that if a migrant manages to get a job in a high-skilled occupation that accurately reflects her educational skills, she will be rewarded substantially more than otherwise (12 percent as opposed to 7.1 percent). While for Germany, the evidence of the above tendency is not that strong; the penalty for under-educated migrants working in high-skilled occupations (-15.6 percent) is significantly larger than that of the pooled occupational sample (-3.6 percent).

Focusing on low-skilled occupations, the penalty for natives being undereducated in Germany (-11.8 percent) is substantially higher than its equivalent in Table 6 (-6.7 percent). In France, the returns to education of correctly matched natives and

\footnotetext{
${ }^{28}$ Results are available upon request.
} 
immigrants working in low-skilled occupations are substantially lower than those of the pooled occupational sample. Comparing further the estimates between the correctly matched French native and immigrant workers in low-skilled occupations in Table 6 shows that French migrants have a significantly lower returns to education compared to natives (3.8 percent as opposed to 6.3 percent) in the case where their education matches the one prevailing in a certain low-skilled occupation.

Overall, contrasting the regression results obtained using the Mincerian and Realized-Matches Approach regarding the educational attainment of native and foreignborn workers in Austria, Germany, and France, highlights the importance of accounting for potential mis-matches due to the over- or under-education of workers. Using the Realized-Matches Approach and accounting for the usual years of schooling across different occupations rather than just actual years of schooling, better explains the variation in earnings and allows for a more nuanced explanation of why foreign-born workers have lower rates of return to education than natives. While returns to 'typical' education are similar between native and immigrant workers, over-educated immigrants have significantly lower returns to education compared to natives. There is some weak evidence that foreign-born workers are penalized less for being under-educated than natives. 


\section{Conclusion}

This paper attempts to explain the relationship between education and wages among native and foreign-born workers in Austria, France, and Germany. While a standard Mincerian specification suggests a significant gap in returns to education between natives and workers, this study investigates to what extent these differences result from a potential mis-match between the actual and the 'typical' years of schooling typical for a certain occupation. The results of the Realised-Matches Approach provide an explanation, suggesting a more nuanced picture: returns to the 'typical' education are very similar for natives and the foreign-born, while natives are over-compensated compared to foreign-born workers for each over-educated worker. Natives tend to be over-represented among over-educated workers (e.g. in France and Germany), which explains why in the standard Mincerian specification natives appear to have higher returns to education. There is limited evidence that foreign-born workers are less penalised for being under-educated compared to native workers although a significant difference is only observed in Austria.

Due to data limitations and methodology changes of variable definitions across and within countries, it was not possible to carry out a regression analysis over time and therefore verify or disprove the Search and Match theory or the Human Capital theory, which both require a time dimension in the data. However, the regression analysis confirms the Assignment theory hypothesis of under-educated workers being penalized more than the rewarded, over-educated workers in Germany and Austria. The Technological Change theory is confirmed in the analysis for France where the incidence of over-educated migrants from non-EU countries is triple the one for overeducated migrants from EU countries.

The main conclusions can be summarised as follows: Foreign-born workers find it slightly more difficult to find employment in occupations matching their level of education. When they do find employment in such occupations, their earnings are on par with those of natives of similar educational attainment. However, compared to natives, foreign-born workers have lower returns to over-education, which drives the gap in earnings between natives and the foreign-born. This is evidence for the difference in the 'quality' of education among natives and foreign-born employees. That is 
foreign-born workers both find it more difficult to find jobs matching their education and may also face lower earnings than natives for similar levels of education beyond the prevailing level in a given occupation.

When distinguishing between highly skilled and low-skilled occupations, France rewards over-educated and correctly educated migrants in highly skilled occupations substantially more than natives. While the same is valid for Germany in the case of the 'typical' education of migrants across highly skilled occupations, the penalty for being an under-educated migrant working in a highly skilled occupation is significantly higher than that for natives.

Focusing on low-skilled occupations, it is worth noting that in France the returns to education for correctly matched natives and immigrants are substantially lower than those for the pooled occupational sample. Furthermore, French migrants in low-skilled occupations have significantly lower returns to education compared to natives in the case where their education matches the one prevailing in a certain low-skilled occupation.

Differences in immigration policies (access to labour markets) do not play a role while comparing the educational returns of native and migrant workers who have found a position perfectly corresponding to their education. The gap between educational returns of natives and workers across all countries in this case is non-existent. However, migrant-conservative labour markets in the EU countries of France, Germany, and Austria reward native workers more than they reward immigrants in the case these workers have higher education than that 'typical' for their occupation. In contrast, the more migrant-friendly labour markets in the UK and the US do not distinguish between natives and immigrants in rewarding over-education. The fact that the UK and the US pursue relatively liberal immigrant labour market policies and do not punish migrants for being over-educated, compared to the rest of the EU, could potentially explain the fact that the UK and the US attract some of the best educated and highly skilled immigrants despite the uncertainties of the matching mechanism in their respective labour markets.

The findings of this paper are generally in accordance with previous studies for the US and the UK, which also find little difference in remuneration for correctly matched native and foreign-born employees coupled with an over-representation of 
Working Paper Series, 2010, Vol. 20(1), 1-40

native workers in correctly matched positions and for those over-educated in their positions. Furthermore, in the absence of mis-matches across occupations (over- and under-education), the returns to 'typical' education using the Realized-Matches Approach for both groups of employees are substantially higher than their returns to education in the Mincerian Framework in all countries. 


\section{Appendix}

\section{A.1. Highest Educational Degree Achieved by Workers and Years of Schooling}

(Austria, 2000)

\begin{tabular}{lc}
\hline \multicolumn{1}{c}{ Highest Educational Degree } & Years of Schooling \\
\hline Less than $1^{\text {st }}$ stage of secondary level & 5 \\
$1^{\text {st }}$ stage of secondary level & 8 \\
$2^{\text {nd }}$ stage of secondary level & 12 \\
$3^{\text {rd }}$ level other than university degree & 13 \\
Initial university degree or equivalent & 16 \\
Higher university degree or post-doctorate & 18 \\
\hline
\end{tabular}

Source: Luxembourg Income Study

The education variable in the Luxembourg Income Study is constructed according to the ISCED 97 international standard classification of education; calculations are done by the author.

\section{A.2. Highest Educational Degree Achieved by Workers and Years of Schooling}

(France, 2000)

\begin{tabular}{lc}
\hline \multicolumn{1}{c}{ Highest Educational Degree } & Years of Schooling \\
\hline BEPC, Brevet des Colleges & 9 \\
Degree lycee & 11 \\
A-E baccalaureat & 12 \\
Baccalaureat Professionel & 13 \\
CAP, BEP & 11 \\
Technical & 12 \\
$1^{\text {st }}$ cycle & 14 \\
$2^{\text {nd }}$ cycle & 16 \\
$3^{\text {rd }}$ cycle & 18 \\
\hline
\end{tabular}

Source: Luxembourg Income Study, calculations are done by the author. 
A.3. Highest Educational Degree Achieved by Workers and Years of Schooling

(Germany, 2000)

\begin{tabular}{lc}
\hline Highest Educational Degree & Years of Schooling \\
\hline & \\
Secondary education (Hauptschule) & 9 \\
Secondary education, 1st stage & 10 \\
(Realschule) & 13 \\
Secondary education, 2nd stage (Abitur) & 12 \\
Academy (Fachoberschule) & 13 \\
Technical college (Fachhochschule) & 18 \\
University & 18 \\
Foreign university & 13 \\
Technical school (GDR) & 18 \\
University GDR & 12 \\
Other diploma & \\
\hline
\end{tabular}

Source: Luxembourg Income Study, calculations are done by the author. 
Working Paper Series, 2010, Vol. 20(1), 1-40

Table 1. Distribution of Key Statistics by Country and Status (\%)

\begin{tabular}{|c|c|c|c|c|c|c|c|c|c|}
\hline & $\begin{array}{l}\text { Average } \\
\text { years of } \\
\text { education }\end{array}$ & $\begin{array}{l}\text { Correctly } \\
\text { educated }\end{array}$ & $\begin{array}{l}\text { Over- } \\
\text { educated }\end{array}$ & $\begin{array}{l}\text { Under- } \\
\text { educated }\end{array}$ & $\begin{array}{l}\text { Over- } \\
\text { educ. in } \\
\text { a low- } \\
\text { skilled } \\
\text { occ. }\end{array}$ & $\begin{array}{l}\text { Under- } \\
\text { educ. in } \\
\text { a highly } \\
\text { skilled } \\
\text { occ. }\end{array}$ & Married & $\begin{array}{l}\text { Permanent } \\
\text { Employee }\end{array}$ & Supervisor \\
\hline \multicolumn{10}{|l|}{ Austria } \\
\hline Natives & 12 & 73.33 & 4.86 & 21.82 & 3 & 7 & 60.1 & 50.7 & 64.9 \\
\hline $\begin{array}{l}\text { Foreign- } \\
\text { born }\end{array}$ & 12 & 61.54 & 10.99 & 27.47 & 9 & 22 & 74.0 & 43.6 & 61.2 \\
\hline \multicolumn{10}{|l|}{ France } \\
\hline Natives & 11 & 36.92 & 25.58 & 37.49 & 25 & 38 & 56.8 & 54.2 & 48.7 \\
\hline $\begin{array}{l}\text { Foreign- } \\
\text { born }\end{array}$ & 9 & 27.22 & 21.27 & 51.5 & 20 & 44 & 71.2 & 50.8 & 50.1 \\
\hline \multicolumn{10}{|c|}{ Germany } \\
\hline Natives & 10 & 50.11 & 36.24 & 13.65 & 36 & 23 & 60.6 & 50.4 & 14.1 \\
\hline $\begin{array}{l}\text { Foreign- } \\
\text { born }\end{array}$ & 9 & 45.54 & 35.78 & 18.67 & 36 & 29 & 76.8 & 48.2 & 8.1 \\
\hline
\end{tabular}


Chart 1. Distribution of Years of Schooling, Austria (2000)

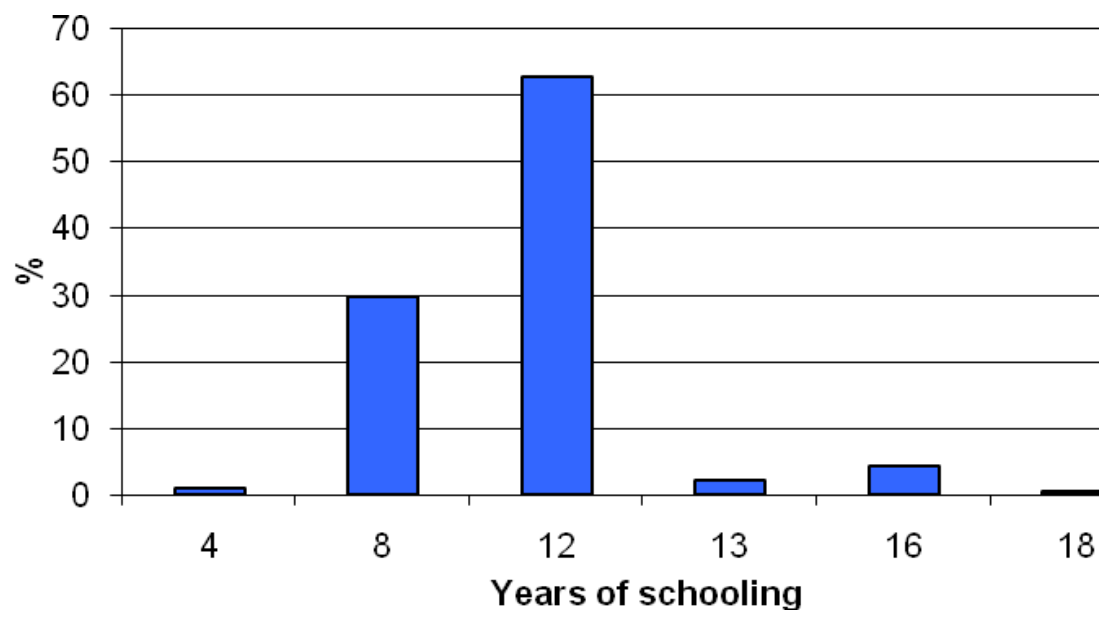

Chart 2. Distribution of Years of Schooling, France (2000)

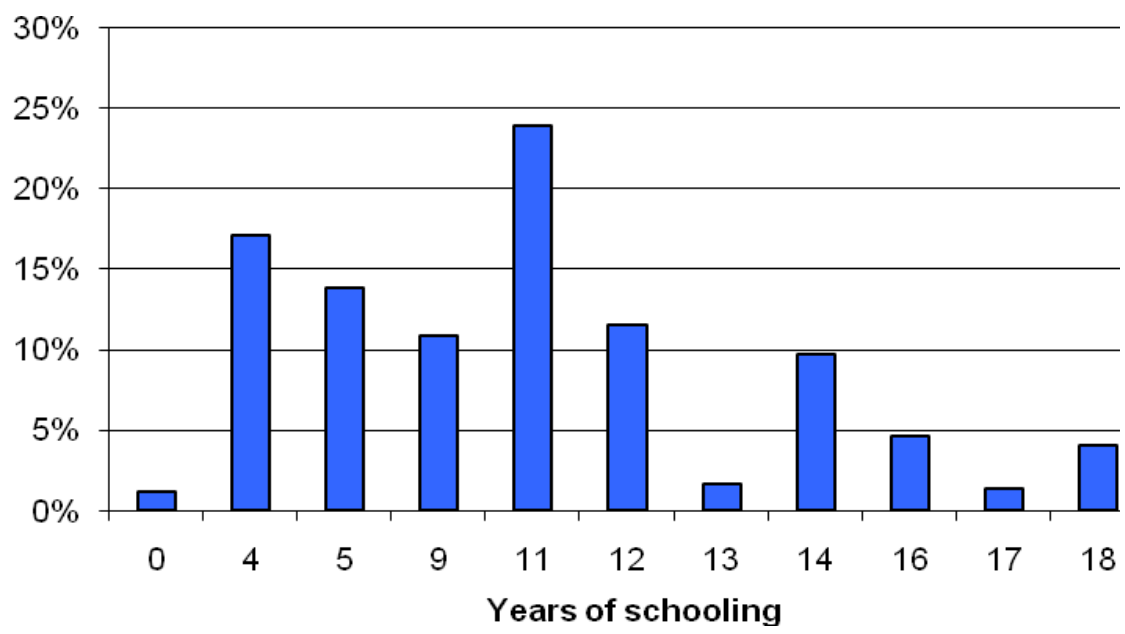

Chart 3. Distribution of Years of Schooling, Germany (2000)

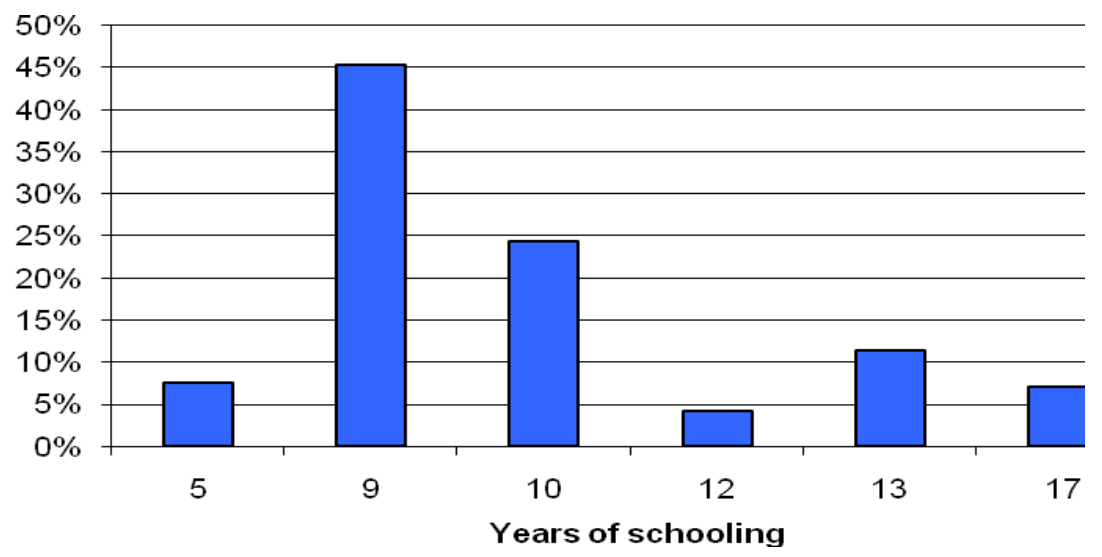


Table 2a. Difference between Native and Foreign-Born Workers' Education across Countries (percentage points)

\begin{tabular}{lrcc}
\hline & $\begin{array}{c}\text { Correctly } \\
\text { educated }\end{array}$ & $\begin{array}{l}\text { Over- } \\
\text { educated }\end{array}$ & $\begin{array}{l}\text { Under- } \\
\text { educated }\end{array}$ \\
\hline Austria & 11.79 & -6.13 & -5.65 \\
France & 9.70 & 4.31 & -14.01 \\
Germany & 4.57 & 0.46 & -5.02 \\
UK* & 15.00 & -19.00 & 3.00 \\
USA** & 14.60 & 3.99 & -18.65 \\
\hline
\end{tabular}

* Lindley \& Linton (2006) Estimates for white male natives vs. white male immigrants between 1993-2003.

** Chiswick \& Miller (2007) estimates are for males only based on the 2000 Census data.

Table 2b. Ratio of Native to Foreign-Born across Realised Matches and Countries (\%)

\begin{tabular}{|c|c|c|c|c|c|}
\hline & $\begin{array}{l}\text { 'Typical' } \\
\text { education }\end{array}$ & $\begin{array}{c}\text { Over- } \\
\text { education }\end{array}$ & $\begin{array}{l}\text { Under- } \\
\text { education }\end{array}$ & $\begin{array}{c}\text { Over- } \\
\text { educated in a } \\
\text { low-skilled } \\
\text { occup. }\end{array}$ & $\begin{array}{c}\text { Under- } \\
\text { educated in a } \\
\text { highly skilled } \\
\text { occup. }\end{array}$ \\
\hline France & 1.32 & 1.19 & 0.73 & 1.25 & 0.86 \\
\hline Germany & 1.07 & 1.09 & 0.66 & 1 & 0.79 \\
\hline Austria & 1.19 & 0.44 & 0.79 & 0.33 & 0.32 \\
\hline UK* & 1.71 & 0.66 & 1.13 & $\mathrm{n} / \mathrm{a}$ & $n / a$ \\
\hline $\mathbf{U S}^{\wedge}$ & 1.53 & 1.14 & 0.58 & $\mathrm{n} / \mathrm{a}$ & $\mathrm{n} / \mathrm{a}$ \\
\hline
\end{tabular}


Table 3. OLS Estimates of Earnings: Mincer vs. the Realized Matches Approach France, (2000)

\begin{tabular}{|c|c|c|c|c|}
\hline & \multicolumn{2}{|c|}{ Natives } & \multicolumn{2}{|c|}{ Foreign-born } \\
\hline & Mincerian & $\begin{array}{l}\text { Realized } \\
\text { Match }\end{array}$ & Mincerian & $\begin{array}{c}\text { Realized } \\
\text { Match }\end{array}$ \\
\hline Education & $\begin{array}{l}0.062^{* * *} \\
(0.001)\end{array}$ & (b) & $\begin{array}{l}0.051^{* * *} \\
(0.005)\end{array}$ & (b) \\
\hline 'Typical' Education ${ }^{(a)}$ & (b) & $\begin{array}{l}0.080^{* * *} \\
(0.002)\end{array}$ & (b) & $\begin{array}{l}0.071^{* * *} \\
(0.006)\end{array}$ \\
\hline Over-education & (b) & $\begin{array}{l}0.068^{* * *} \\
(0.004)\end{array}$ & (b) & $\begin{array}{l}0.042^{* * *} \\
(0.011)\end{array}$ \\
\hline Under-education & (b) & $\begin{array}{c}-0.042^{* * *} \\
(0.002)\end{array}$ & (b) & $\begin{array}{l}-0.036^{* * *} \\
(0.006)\end{array}$ \\
\hline Experience & $\begin{array}{l}0.031^{* * *} \\
(0.001)\end{array}$ & $\begin{array}{l}0.032^{* * *} \\
(0.002)\end{array}$ & $\begin{array}{l}0.026^{* * *} \\
(0.006)\end{array}$ & $\begin{array}{l}0.023^{* * *} \\
(0.005)\end{array}$ \\
\hline Experience $^{2} / 100$ & $\begin{array}{l}-0.038^{* * *} \\
(0.004)\end{array}$ & $\begin{array}{c}-0.044^{* * *} \\
(0.004)\end{array}$ & $\begin{array}{c}-0.025^{* * *} \\
(0.010)\end{array}$ & $\begin{array}{r}-0.023^{* * *} \\
(0.009)\end{array}$ \\
\hline Married dummy & $\begin{array}{l}0.006 \\
(0.011)\end{array}$ & $\begin{array}{r}0.001 \\
(0.011)\end{array}$ & $\begin{array}{l}-0.009 \\
(0.041)\end{array}$ & $\begin{array}{c}0.006 \\
(0.040)\end{array}$ \\
\hline Private/State Dummy & $\begin{array}{l}-0.101^{* * *} \\
(0.011)\end{array}$ & $\begin{array}{c}-0.074^{* * *} \\
(0.011)\end{array}$ & $\begin{array}{l}-0.120^{* * *} \\
(0.049)\end{array}$ & $\begin{array}{l}-0.065 \\
(0.052)\end{array}$ \\
\hline $\begin{array}{l}\text { Permanent contract } \\
\text { dummy }\end{array}$ & $\begin{array}{l}0.352^{* * *} \\
(0.018)\end{array}$ & $\begin{array}{l}0.327^{* * *} \\
(0.018)\end{array}$ & $\begin{array}{l}0.288^{* * *} \\
(0.051)\end{array}$ & $\begin{array}{l}0.262^{* * *} \\
(0.050)\end{array}$ \\
\hline $\begin{array}{l}\text { Supervisory role } \\
\text { dummy }\end{array}$ & $\begin{array}{l}0.238^{* * *} \\
(0.013)\end{array}$ & $\begin{array}{l}0.212^{* * *} \\
(0.012)\end{array}$ & $\begin{array}{l}0.337^{* * *} \\
(0.043)\end{array}$ & $\begin{array}{l}0.304^{* * *} \\
(0.043)\end{array}$ \\
\hline Controls & yes & yes & yes & yes \\
\hline Constant & $\begin{array}{l}7.528^{* * *} \\
(0.045)\end{array}$ & $\begin{array}{l}7.291^{* * *} \\
(0.049)\end{array}$ & $\begin{array}{l}7.571^{* * *} \\
(0.141)\end{array}$ & $\begin{array}{l}7.333^{* * *} \\
(0.146)\end{array}$ \\
\hline$R^{2}$ & 0.42 & 0.44 & 0.38 & 0.40 \\
\hline $\begin{array}{l}\text { Number of } \\
\text { Observations }\end{array}$ & 9143 & 9143 & 921 & 921 \\
\hline
\end{tabular}

Notes: (a) Computed by using the modal value of years of schooling across occupations

(b) Variable not included

Huber-White standard errors are in parentheses.

*** denotes significance at the 1 percent significance level; ** denotes significance at the 5 percent significance level; * denotes significance at the 10 percent significance level.

Married dummy - reference group is not married, divorced or widowed

Private/State dummy - reference group is state-owned company

Permanent contract dummy - reference group is fixed-term contract

Supervisory role dummy - reference group is no supervisory role of the worker

Controls - region, gender (reference group is female), industry (reference groups are services and agriculture)

Source: Luxemburg Income Study: www.lisproject.org 
Table 4. OLS Estimates of Earnings: Mincer vs. the Realized Matches Approach Germany, (2000)

\begin{tabular}{|c|c|c|c|c|}
\hline & \multicolumn{2}{|c|}{ Natives } & \multicolumn{2}{|c|}{ Foreign-born } \\
\hline & Mincerian & $\begin{array}{l}\text { Realized } \\
\text { Match }\end{array}$ & Mincerian & $\begin{array}{l}\text { Realized } \\
\text { Match }\end{array}$ \\
\hline Education & $\begin{array}{l}0.065^{\text {*** }} \\
(0.003)\end{array}$ & (b) & $\begin{array}{l}0.031^{* * *} \\
(0.005)\end{array}$ & (b) \\
\hline ‘Typical' Education ${ }^{(a)}$ & (b) & $\begin{array}{l}0.086^{* * *} \\
(0.004)\end{array}$ & (b) & $\begin{array}{l}0.096^{* * *} \\
(0.011)\end{array}$ \\
\hline Over-education & (b) & $\begin{array}{l}0.036^{* * *} \\
(0.006)\end{array}$ & (b) & $\begin{array}{l}0.012^{*} \\
(0.007)\end{array}$ \\
\hline Under-education & (b) & $\begin{array}{c}-0.067^{* * *} \\
(0.009)\end{array}$ & (b) & $\begin{array}{l}-0.051^{\text {**** }} \\
(0.018)\end{array}$ \\
\hline Experience & $\begin{array}{l}0.049^{* * *} \\
(0.004)\end{array}$ & $\begin{array}{l}0.049^{* * *} \\
(0.004)\end{array}$ & $\begin{array}{l}0.038^{* * *} \\
(0.007)\end{array}$ & $\begin{array}{l}0.039^{* * *} \\
(0.007)\end{array}$ \\
\hline Experience $^{2} / 100$ & $\begin{array}{l}-0.086^{* * *} \\
(0.007)\end{array}$ & $\begin{array}{c}-0.085^{* * *} \\
(0.007)\end{array}$ & $\begin{array}{c}-0.056^{* * *} \\
(0.014)\end{array}$ & $\begin{array}{r}-0.058^{* * *} \\
(0.013)\end{array}$ \\
\hline Married dummy & $\begin{array}{l}-0.030^{*} \\
(0.017)\end{array}$ & $\begin{array}{c}-0.032^{*} \\
(0.018)\end{array}$ & $\begin{array}{l}-0.031 \\
(0.052)\end{array}$ & $\begin{array}{l}-0.020 \\
(0.051)\end{array}$ \\
\hline Private/State Dummy & $\begin{array}{c}-0.157^{* * *} \\
(0.018)\end{array}$ & $\begin{array}{c}-0.132^{* * *} \\
(0.019)\end{array}$ & $\begin{array}{c}-0.117^{* * *} \\
(0.047)\end{array}$ & $\begin{array}{l}-0.051 \\
(0.047)\end{array}$ \\
\hline $\begin{array}{l}\text { Permanent contract } \\
\text { dummy }\end{array}$ & $\begin{array}{l}0.352^{* * *} \\
(0.024)\end{array}$ & $\begin{array}{l}0.358^{* * *} \\
(0.024)\end{array}$ & $\begin{array}{l}0.346^{* * *} \\
(0.051)\end{array}$ & $\begin{array}{l}0.363^{* * *} \\
(0.051)\end{array}$ \\
\hline $\begin{array}{l}\text { Supervisory role } \\
\text { dummy }\end{array}$ & $\begin{array}{l}0.355^{* * *} \\
(0.019)\end{array}$ & $\begin{array}{l}0.351^{* * *} \\
(0.019)\end{array}$ & $\begin{array}{l}0.478^{* * *} \\
(0.062)\end{array}$ & $\begin{array}{l}0.408^{* * *} \\
(0.061)\end{array}$ \\
\hline Controls & yes & yes & yes & yes \\
\hline Constant & $\begin{array}{l}5.866^{* * *} \\
(0.080)\end{array}$ & $\begin{array}{l}5.660^{* * *} \\
(0.082)\end{array}$ & $\begin{array}{l}6.192^{* * *} \\
(0.178)\end{array}$ & $\begin{array}{l}5.633^{* * *} \\
(0.199)\end{array}$ \\
\hline$R^{2}$ & 0.42 & 0.44 & 0.50 & 0.53 \\
\hline $\begin{array}{l}\text { Number of } \\
\text { Observations }\end{array}$ & 9069 & 9069 & 1333 & 1333 \\
\hline
\end{tabular}

Notes: (a) Computed by using the modal value of years of schooling across occupations

(b) Variable not included

Huber-White standard errors are in parentheses.

*** denotes significance at the 1 percent significance level; ** denotes significance at the 5 percent significance level; * denotes significance at the 10 percent significance level.

Married dummy - reference group is not married, divorced or widowed

Private/State dummy - reference group is state-owned company

Permanent contract dummy - reference group is fixed-term contract

Supervisory role dummy - reference group is no supervisory role of the worker

Controls - region, gender (reference group is female), industry (reference groups are services and agriculture)

Source: Luxemburg Income Study: www.lisproject.org 
Table 5. OLS Estimates of Earnings: Mincer vs. the Realized Matches Approach Austria, (2000)

\begin{tabular}{|c|c|c|c|c|}
\hline & \multicolumn{2}{|c|}{ Natives } & \multicolumn{2}{|c|}{ Foreign-born } \\
\hline & Mincerian & $\begin{array}{l}\text { Realized } \\
\text { Match }\end{array}$ & Mincerian & $\begin{array}{l}\text { Realized } \\
\text { Match }\end{array}$ \\
\hline Education & $\begin{array}{l}0.078^{* * *} \\
(0.006)\end{array}$ & (b) & $\begin{array}{l}0.041^{* * *} \\
(0.018)\end{array}$ & (b) \\
\hline 'Typical' Education ${ }^{a}$ & (b) & $\begin{array}{l}0.088^{* * *} \\
(0.009)\end{array}$ & (b) & $\begin{array}{l}0.107^{* * *} \\
(0.028)\end{array}$ \\
\hline Over-education & (b) & $\begin{array}{l}0.077^{* * *} \\
(0.010)\end{array}$ & (b) & $\begin{array}{c}0.025^{*} \\
(0.023)\end{array}$ \\
\hline Under-education & (b) & $\begin{array}{c}-0.072^{* * *} \\
(0.009)\end{array}$ & (b) & $\begin{array}{l}-0.041^{* *} \\
(0.021)\end{array}$ \\
\hline Experience & $\begin{array}{l}0.017^{* * *} \\
(0.004)\end{array}$ & $\begin{array}{l}0.017^{* * *} \\
(0.004)\end{array}$ & $\begin{array}{l}0.057^{* * *} \\
(0.019)\end{array}$ & $\begin{array}{l}0.056^{* * *} \\
(0.019)\end{array}$ \\
\hline Experience $^{2} / 100$ & $\begin{array}{l}-0.017^{* *} \\
(0.009)\end{array}$ & $\begin{array}{l}-0.018^{* *} \\
(0.009)\end{array}$ & $\begin{array}{l}-0.097^{* * *} \\
(0.039)\end{array}$ & $\begin{array}{c}-0.096^{* * *} \\
(0.039)\end{array}$ \\
\hline Married dummy & $\begin{array}{l}-0.071^{* * *} \\
(0.024)\end{array}$ & $\begin{array}{c}-0.069^{* * *} \\
(0.024)\end{array}$ & $\begin{array}{l}-0.220^{* * *} \\
(0.105)\end{array}$ & $\begin{array}{l}-0.225^{* * *} \\
(0.099)\end{array}$ \\
\hline Private/State Dummy & $\begin{array}{c}-0.074^{* * *} \\
(0.027)\end{array}$ & $\begin{array}{c}-0.069^{* * *} \\
(0.026)\end{array}$ & $\begin{array}{c}-0.244^{* * *} \\
(0.111)\end{array}$ & $\begin{array}{l}-0.195^{*} \\
(0.108)\end{array}$ \\
\hline $\begin{array}{l}\text { Permanent contract } \\
\text { dummy }\end{array}$ & $\begin{array}{l}0.320^{* * *} \\
(0.054)\end{array}$ & $\begin{array}{l}0.326^{* * *} \\
(0.054)\end{array}$ & $\begin{array}{c}0.192 \\
(0.156)\end{array}$ & $\begin{array}{l}0.255^{*} \\
(0.162)\end{array}$ \\
\hline $\begin{array}{l}\text { Supervisory role } \\
\text { dummy }\end{array}$ & $\begin{array}{l}0.204^{* * *} \\
(0.21)\end{array}$ & $\begin{array}{l}0.206^{* * *} \\
(0.021)\end{array}$ & $\begin{array}{c}0.152 \\
(0.203)\end{array}$ & $\begin{array}{l}0.174^{*} \\
(0.108)\end{array}$ \\
\hline Controls & yes & yes & yes & yes \\
\hline Constant & $\begin{array}{l}7.824^{* * *} \\
(0.133)\end{array}$ & $\begin{array}{l}7.691^{* * *} \\
(0.162)\end{array}$ & $\begin{array}{l}8.272^{* * *} \\
(0.376)\end{array}$ & $\begin{array}{l}7.463^{* * *} \\
(0.511)\end{array}$ \\
\hline$R^{2}$ & 0.46 & 0.46 & 0.44 & 0.47 \\
\hline $\begin{array}{l}\text { Number of } \\
\text { Observations }\end{array}$ & 1747 & 1747 & 152 & 152 \\
\hline
\end{tabular}

Notes: (a) Computed by using the modal value of years of schooling across occupations

(b) Variable not included

Huber-White standard errors are in parentheses.

*** denotes significance at the 1 percent significance level; ** denotes significance at the 5 percent significance level; * denotes significance at the 10 percent significance level.

Married dummy - reference group is not married, divorced or widowed

Private/State dummy - reference group is state-owned company

Permanent contract dummy - reference group is fixed-term contract

Supervisory role dummy - reference group is no supervisory role of the worker

Controls - region, gender (reference group is female), industry (reference groups are services and agriculture)

Source: Luxemburg Income Study: www.lisproject.org 
Table 6. Regression Estimates of the Returns to Education on Earnings by the Realized Matches Approach across Countries

\begin{tabular}{|c|c|c|c|c|c|c|c|c|c|}
\hline & \multicolumn{3}{|c|}{ Correctly Educated } & \multicolumn{3}{|c|}{ Overeducated } & \multicolumn{3}{|c|}{ Undereducated } \\
\hline & Natives & Immigrants & $\begin{array}{l}\text { Native- } \\
\text { Imm. } \\
\text { Gap }\end{array}$ & Natives & Immigrants & $\begin{array}{l}\text { Native- } \\
\text { Imm. } \\
\text { Gap }\end{array}$ & Natives & Immigrants & $\begin{array}{c}\text { Native- } \\
\text { Imm. } \\
\text { Gap }\end{array}$ \\
\hline France & 0.08 & 0.071 & 0.009 & 0.068 & 0.042 & $0.026^{* * *}$ & -0.042 & -0.036 & $-0.006^{*}$ \\
\hline Germany & 0.086 & 0.096 & -0.01 & 0.036 & 0.012 & $0.024^{* * *}$ & -0.067 & -0.051 & -0.016 \\
\hline Austria & 0.088 & 0.107 & -0.019 & 0.077 & 0.025 & 0.052 & -0.072 & -0.041 & $-0.031^{* *}$ \\
\hline $\mathrm{UK}^{1}$ & 0.069 & 0.054 & 0.015 & 0.025 & 0.009 & 0.016 & -0.036 & -0.044 & 0.008 \\
\hline $\mathrm{USA}^{2}$ & 0.153 & 0.153 & 0 & 0.056 & 0.045 & 0.011 & -0.066 & -0.022 & $-0.044^{* * *}$ \\
\hline
\end{tabular}


Table 7. Regression Estimates of Highly Skilled vs. Low-Skilled Occupations Highly skilled occupations

Low-skilled occupations

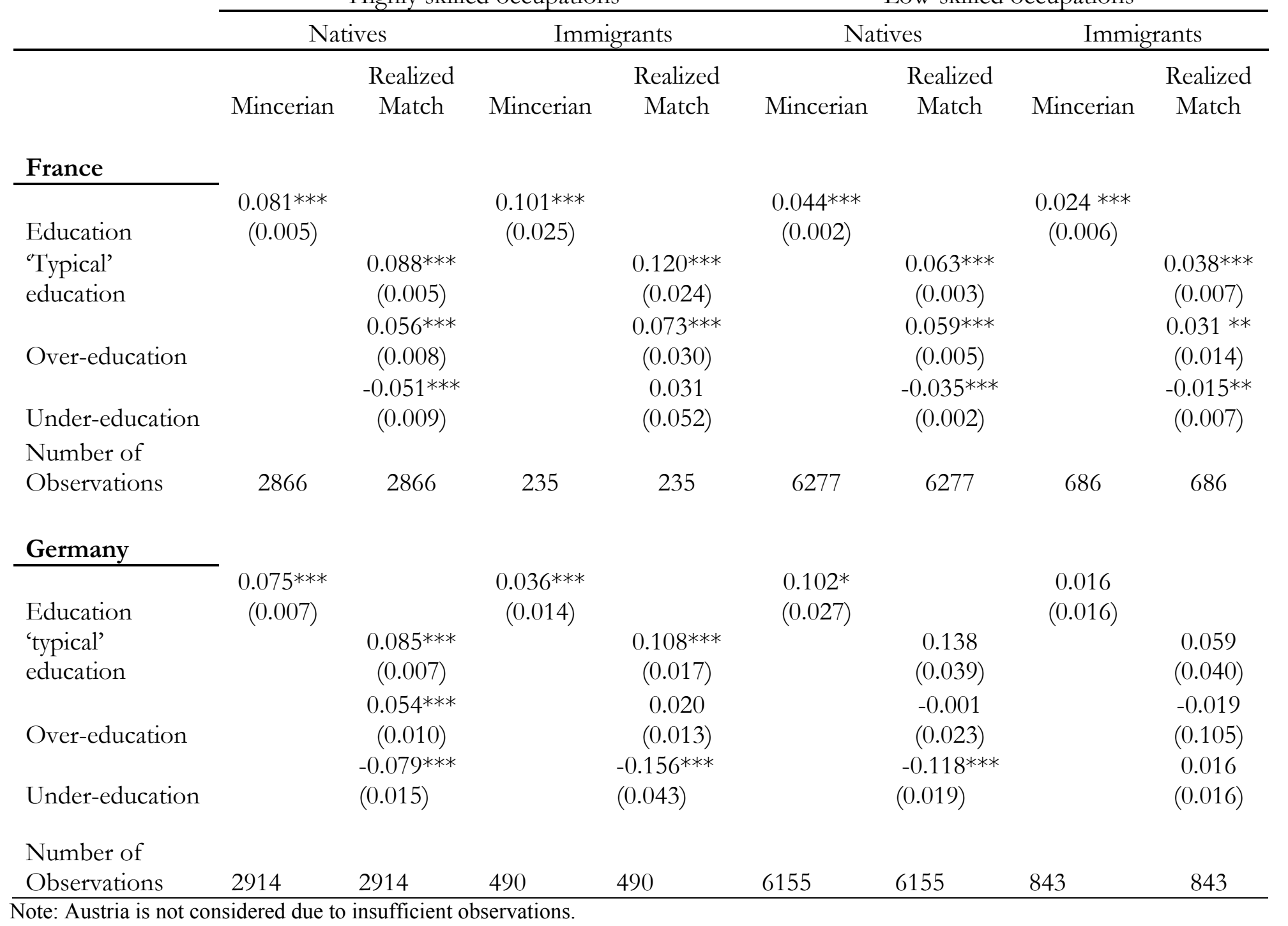




\section{References}

Baker, M., and Benjamin, D., (1994). "The Performance of Immigrants in the Canadian Labor Market”, Journal of Labor Economics, Vol. 12, No. 3, pp. 369-405.

Battu, H. and Sloane, P., (2004). "Overeducation and Ethnic Minorities in Britain", The Manchester School, Vol. 72 No. 4, 535-559.

Becker, Gary S., (1964). Human Capital: A Theoretical and Empirical Analysis, With Special Reference to Education, Columbia University Press, New York.

Becker Gary S., (1964, 1993, 3rd ed.). "Human Capital: A Theoretical and Empirical Analysis, with Special Reference to Education”. Chicago, University of Chicago Press.

Becker, Gary S., and Chiswick, B. R.,(1966). "Education and the Distribution of Earnings", American Economic Review, Vol. 56, No. 2, pp. 358-369.

Biffi, Gudrun, (2006). SOPEMI Report on Labour Migration. Austria 2005-06.

Boeri, T., Hanson, Howard H., McCormick B., (2002) "Immigration policy and the welfare system”, The William Davidson Institute, Oxford University Press.

Caldeira, Hose M., Castello, J., Esteves, A., Ferrer, A., Fonseca, M., Jamin, J., Koff, H., Lostia, A., Malheiros, J., Molina, I., Tricada E., and van der Leun, J., (1999) "Migrant Integration in European Cities", Centre for European Migration and Ethnic Studies (CEMES) for Ethnobarometer Programme.

Chiswick, Barry R., (1999). “Are Immigrants Favourably Self-Selected?" American Economic Review, Vol. 89, No. 2, pp. 181-5.

Chiswick, Barry R., (1980). "The Earnings of White and Coloured Male Immigrants in Britain", Economica, Vol. 47, pp. 81-87.

Chiswick, Barry R., (1978). "The Effect of Americanization on the Earnings of Foreignborn Men”, Journal of Political Economy, Vol. 86, No. 5, pp. 897-921.

Chiswick, Barry R., and Miller, P. W., (2007), "The International Transferability of Immigrants' Human capital", Economics of Education Review, Volume 28, No 2, April 2009, Pages 162-169.

Chiswick, Barry R., and Miller, P. W., (2005). "Why Is the Payoff to Schooling Smaller for Immigrants?", IZA Discussion Paper No. 1731.

Cohn, E. and Khan, S., (1995). "The Wage Effects of Over-schooling Revisited", Labour Economics, Vol. 2, No. 1, pp. 67-76. 
Daly, M. C., Buchel, F. and Duncan, G. J., (2000). "Premiums and Penalties for Surplus and Deficit Education: Evidence from the United States and Germany", Economics of Education Review, Vol. 19, No. 2, pp. 169-178.

Duncan, G. and Hoffman, S. D., (1981). "The Incidence and Wage Effects of Overeducation", Economics of Education Review, Vol. 1, No. 1, pp. 75-86.

Dustmann, Christian, (1993). "Earnings Adjustment of Temporary Migrants", Journal of Population Economics, Vol. 6, No. 2, pp.153-168.

Entorf, H., Minoiu N., (2005) "What a Difference Immigration Policy Makes: A Comparison of PISA Scores in Europe and Traditional Countries of Immigration", German Economic Review, Vol. 6, No 3, pp. 355-376.

Groot, W. and Maasen van den Brink, H., (2000). "Overeducation in the Labour Market“" a Meta-Analysis", Economics of Education Review, Vol. 19, pp. 149158.

Hartog, J., (2000). "Over-education and Earnings: Where Are We, Where Should We Go?", Economics of Education Review, Vol. 19, No. 2, pp. 131-147.

Haus, Leah, (1999). "Labor Unions and Immigration Policy in France”, International Migration Review, Vol. 33, No. 3, pp. 683-716.

Kiker, B. F., Santos, M. C. and Mendes De Oliveira, M., (1997). "Overeducation and Undereducation: Evidence for Portugal", Economics of Education Review, Vol. 16, No. 2, pp. 111-125.

Lindley, J. and Lenton, P., (2006). "The Over-Education of UK Immigrants: Evidence from the Labour Force Survey", Sheffield Economic Research Paper Series, SEPR No. 2006001.

McGuiness, S., (2006). "Over-education in the Labour Market", Journal of Economic Surveys, Vol. 20, No 3, pp.387-418.

Mincer, Jacob., (1974). Schooling, Experience and Earnings, National Bureau of Economic Research, Cambridge.

Munich, D., Svejnar, J. \& Terrell, K., (2005) "Returns to Human Capital under the Communist Wage Grid and During the Transition to a Market Economy", Review of Economics and Statistics, 87 (1), pp.100-123

Rumberger, Russell, W. (1981). "The Rising Incidence of over-education in the U.S. Labor Market”, Economics of Education Review, Vol. 1, No. 3, pp. 293-314.

Sattinger, M., (1993). “Assignment Models of the Distribution of Earnings", Journal of Economic Literature, Vol. 31, No2, pp.851-880. 
Working Paper Series, 2010, Vol. 20(1), 1-40

Sicherman, N., (1991). "Overeducation in the Labour market", Journal of Labour Economics, Vol. 9, No 2, 101-122.

Thurow, L., (1975). Generating Inequality. Mechanisms of Distribution in the US Economy. New York: Basic Books.

Verdugo, R. and Verdugo, N., (1989). "The Impact of Surplus Schooling on Earnings: Some Additional Findings", Economics of Education Review, Vol. 22, No. 4, pp. 690-695. 